\title{
Does counseling have an effect on sun protection behaviors and early detection of skin cancer in middle-aged and older Turkish people?
}

\author{
Orta ve ileri yaș Türk insanında güneșten korunmaya yönelik danıșmanlığın güneșten \\ korunma davranıșları ve deri kanserinin erken tanısına etkisi var mıdır?
}

\section{Atiye Oğrum, ๑ Osman Demir*}

Tokat Gaziosmanpașa University Faculty of Medicine, Department of Dermatology and Venereology; *Department of Biostatistics Tokat,

\begin{abstract}
Background and Design: The most important avoidable risk factor for skin cancer is ultraviolet light exposure. The aim of this study is to evaluate the frequency and the effect of counseling on sun protection behaviors and early detection of skin cancer.

Materials and Methods: Five hundred individuals aged $45-75$ years participated in this cross-sectional survey between February $6^{\text {th }}$ and March $07^{\text {th }}$ of 2019. Participants were directed to filled out a questionnaire to understand their sun protection behaviors and learn whether they receive counseling on sun protection and early detection of skin cancer.

Results: Out of the 500 subjects, 283 (56.6\%) were female and 217 (43.4\%) were male. The mean age was $56.65 \pm 9.24$ years (45-75 years). Two hundred and thirty-four (46.8\%) respondents reported having skin-cancer risk factors. The rates of counseling on sun protection and behavior of sun protection were $16 \%$ and $39.4 \%$, respectively. Sun protection counseling was significantly associated with self-reported skincancer risk factors and being a female $(p<0.001 ; p=0.048$, respectively). The rate of counseling on early detection of skin cancer was low (skin selfexamination: $12 \%$; moles monitoring: $11.8 \%$; annual checkup: $13.2 \%$ ). The counseling on sun protection and early detection of skin cancer were significantly associated with behaviors of sun protection and early detection of skin cancer $(p<0.001 ; p<0.001$, respectively). The older age had a negative effect on the counseling and behaviors ( $p=0.047 ; p=0.005$, respectively), however, high level of education had a positive effect $(p=0.024 ; p<0.001)$.

Conclusion: Counseling by healthcare professionals on primary and secondary preventions for the middle-aged and older people seems to be insufficient. Further studies on this issue may be beneficial on prevention and early detection of skin cancer.

Keywords: Middle age, older adult, sun protection, counseling, skin cancer, early detection
\end{abstract}

Öz

Amaç: Deri kanserinin önlenebilir en önemli risk faktörü ultraviyole ışın maruziyetidir. Bu çalışmanın amacı, danışmanlığın güneşten korunma davranışları ve deri kanserinin erken tanısına olan etkisini değerlendirmektir.

Gereç ve Yöntem: Bu kesitsel anket çalışması 06 Şubat-07 Mart 2019 tarihleri arasında, 45-75 yaş aralı̆ındaki 500 birey ile yapıldı. Katılımcılara, güneşten korunmaya yönelik davranışları ile güneşten korunma ve deri kanserinin erken tanısıyla ilgili danışmanlık alıp almadıklarını öğrenmeye yönelik hazırlanan anket cevaplatılı.

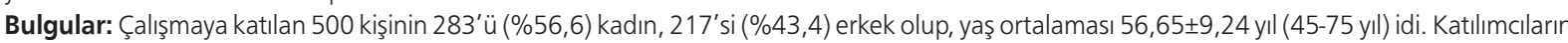
234 'ü $(\% 46,8)$ deri kanseri risk faktörü varlığını beyan etti. Güneşten korunmaya yönelik danışmanlık alma ve davranış sergileme oranları sırasıyla, \%16 ve \%39,6 idi. Güneşten korunmaya yönelik danışmanlık alma, deri kanseri risk faktörü beyanı ve kadın olma ile anlamı oranda ilişkiliydi (sırasıyla, $p<0.001 ; p=0,048$ ). Deri kanserinin erken tanısına yönelik danışmanlık alma oranı düşüktü (kendi kendine deri muayenesi: \%12; ben takibi: \%11,8; yıllık kontrol: \%13,2). Güneşten korunma ve deri kanseri erken tanısına yönelik danışmanlık alma durumları, güneşten

Address for Correspondence/Yazışma Adresi: Atiye Oğrum MD, Tokat Gaziosmanpaşa University Faculty of Medicine, Department of Dermatology and Venereology, Tokat, Turkey Phone: +90 5056025569 E-mail: aogrum@yahoo.com Received/Geliş Tarihi: 19.03.2019 Accepted/Kabul Tarihi: 21.10.2019 ORCID: orcid.org/ 0000-0003-2999-2691

(c) Copyright 2020 by Turkish Society of Dermatology and Venereology

Turkderm - Turkish Archives of Dermatology and Venereology published by Galenos Yayınevi. 


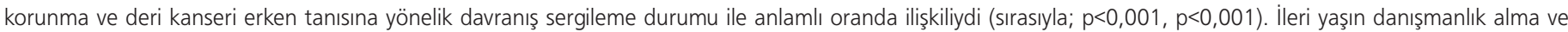
davranışlar üzerine negatif yönde etkisi varken (sırasıyla; $p=0,047 ; p=0,005)$; yüksek eğitim düzeyi pozitif yönde etkiliydi ( $p=0,024 ; p<0,001$ ).

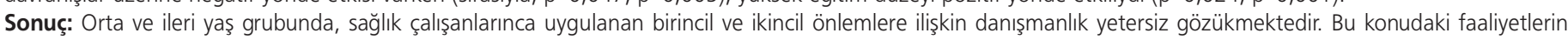
geliştirilmesi, deri kanserinin önlenmesi ve erken tanısında fayda sağlayabilir.

Anahtar Kelimeler: Orta yaş, ileri yaş erişkin, güneşten korunma, danışmanlık, deri kanseri, erken tanı

\section{Introduction}

The incidence of melanoma and non-melanoma skin cancers has been remarkably increasing around the world and also in Turkey ${ }^{1,2}$. The most important and modifiable risk factor of skin cancer is ultraviolet (UV) lights. The main purpose of combating environmentally-induced health problems is to avoid the exposure and take protective measures against causes ${ }^{3}$. Primary prevention for skin cancer refers to protect the skin from UV lights and this is particularly important for children and adolescents who have a high risk of intensive or cumulative exposure to sunlight ${ }^{4}$. Secondary prevention includes early detection and treatment of the skin lesions and is particularly important in the middle-aged and older groups where skin cancers are observed more common ${ }^{5,6}$. Effective implementation of the secondary prevention activities can lead to increasing the life expectancy and quality of life, as well as reducing the cost of treatment ${ }^{6,7}$. Studies conducted in Turkey revealed the level of knowledge about potential dangers of the sun and the sun protection behaviors to be insufficient ${ }^{3,8}$. However, the causative factors for this situation and the issues to be improved are not clearly known. Moreover, there are limited international data on the implementation of the secondary prevention measures for skin cancer, its impact on behaviors and the early detection of skin cancer ${ }^{5,6,9}$. This study aimed to evaluate the counseling on sun protection and early detection of skin cancer in the middle-aged and older groups, and to investigate the effect of these counseling on behaviors and the early detection of skin cancer.

\section{Materials and Methods}

This cross-sectional survey study was conducted with 500 subjects (aged: 45-75 years) admitted to the dermatology outpatient clinic of a tertiary hospital with any complaint between 06 February and 07 March 2019. The sociodemographic characteristics of the participants (gender, age, marital status, education level, income level, occupation) were recorded. Receiving counseling on sun protection and early detection of skin cancer, self-reported skin-cancer risk factors [a large number $(>50)$ of moles fair skin, a family/individual history of skin cancer, history of intense UV exposure (working outdoors or spending much of the leisure time outdoors) or solarium], sun protection behaviors, and behaviors for the early detection of skin cancer were measured by the survey questions.

Before the study, ethical approval was received from the Tokat Gaziosmanpaşa University Faculty of Medicine Local Ethics Committee (approval number: 19-KAEK-016). Informed consent was obtained.

\section{Statistical Analysis}

Statistical analysis was performed using commercial software (IBM SPSS Statistics 20, SPSS Inc., an IBM Co., Somers, NY). Data for continuous variables were given as mean, standard deviation, and for categorical variables were given as frequency, percentage. Chi-square test was used to compare the categorical data between/among groups. A multivariate logistic regression models were implemented to determine the effects of selected covariates on the variables getting counseling on sun protection, sun protection behaviors, following of moles and annual expert control. A p value $<0.05$ was considered as significant.

\section{Results}

The study included 500 middle-aged and older individuals, 283 (56.6\%) females and 217 (43.4\%) males. The mean age was 56.65 \pm 9.24 (47-75 years of age). Two hundred and thirty four (46.8\%) of the participants reported at least one risk factor for skin cancer (melanoma/ squamous cell carcinoma/basal cell carcinoma). The sociodemographic characteristics and self-reported skin-cancer risk factors of the participants are showed in Table 1.

Eighty subjects (16\%) reported that they had received sun protection counseling from a healthcare professional. Also, the rate of counseling on early detection of skin cancer was low (skin self examintation: 12\%; moles monitoring: 11.8\%; annual checkup: 13.2\%). The survey questions and answers of the participants are showed in Table 2.

The rate of sun protection counseling was significantly higher in women $[53 / 283(18.7 \%)]$ than in men $[26 / 217(12 \%)](p=0.048)$. However, when it comes to displaying sun-protection behaviors, following of moles and attending an expert control, the rates were similar in both genders ( $p>0.05)$.

Participants who have self-reported skin cancer risk factor were significantly associated with a higher education level (high school and above) ( $p=0.010)$. Participants with higher education level were more likely to receive counseling on sun protection and follow the changes in moles than those with lower education levels $(p<0.001 ; p=0.003$, respectively).

The rates of sun-protection behaviors were significantly higher in patients who had the counseling on sun protection [59/80 (73.8\%)] $(p<0.001)$. Patients who received counseling on the early detection of skin cancer had significantly higher rates of early detection behaviors ( $p<0.001$ ) (Table 3).

According to the assessment made after adjusting other factors in the logistic regression model, sun protection counseling decreased with being older ( $p=0.047)$. However, being a university graduate, being woman and having a self-reported skin cancer risk factor had positive effects on the counseling ( $p=0.024 ; p=0.014 ; p<0.001$, respectively). Sun-protection behaviors decreased with being older $(p=0.005)$; however, a high level of education and the sun protection counseling had positive effects on behaviors ( $p<0.001$; $p<0.001$, respectively) (Table 4).

A high level of education, sun-protection behaviors and the counseling on required annual check-up had positive effect on following of moles $(p<0.030 ; p<0.001 ; p<0.001$, respectively). Counseling on a following method of moles and necessity of an annual check-up had 
Table 1. The participants' sociodemographic features and the self-reported skin cancer risk factors

\begin{tabular}{|l|l|}
\hline Characteristics & n (\%) \\
\hline Gender & $283(56.6)$ \\
\hline Female & $217(43.4)$ \\
\hline Male &
\end{tabular}

\section{Marital status}

Married

$468(93.6)$

Single

$32(6.4)$

\section{Education level}

Illiterate

Primary education

$55(11)$

High school

$285(57)$

University

$81(16.2)$

Income level

\begin{tabular}{|l|l|}
\hline Low & $54(10.8)$ \\
\hline Middle & $407(81.4)$ \\
\hline High & $39(7.8)$ \\
\hline
\end{tabular}

\section{Occupation}

Housewife

$234(46.8)$

Retired

$108(21.6)$

Civil servant

$53(10.6)$

Worker

$31(6.2)$

Employer

$44(8.8)$

Farmer

$29(5.8)$

Unemployed

$1(0.2)$

Self-reported skin cancer risk factors

At least one risk factor $234(46.8)$

Fair skin

$126(25.2)$

A large number $(>50)$ of moles or other pigmented

$125(25)$

lesions

Individual history of skin cancer

$8(1.6)$

Family history of skin cancer

History of intense UV exposure (working outdoors or spending much of the leisure time outdoors) or solarium

UV: Ultraviolet

positive effects on attending annual expert controls $(p<0.001 ; p<0.001$, respectively) (Table 5)

\section{Discussion}

Counseling on sun protection and early detection of skin cancer are particularly important in the middle-aged and older people, where skin cancer is the most common ${ }^{6}$. In this study, the rates of sun-protection counseling (16\%) and behaviors (38.4\%) were quite low in the middleaged and older populations. In the study of Baron-Epel and Azizi 6 , 793 middle-aged individuals were evaluated by telephone survey in Israel. They found the rates of sun-protection counseling to be $5.2 \%$, related behaviors to be $51.7 \%$. The rate of counseling was lower in our study

\begin{tabular}{|c|c|c|c|c|}
\hline $\begin{array}{l}\text { Question } \\
\text { category }\end{array}$ & Questions & Options & $\begin{array}{l}\text { Healtcare } \\
\text { proveders }\end{array}$ & n (\%) \\
\hline \multirow{6}{*}{$\begin{array}{l}\text { Counseling } \\
\text { on sun } \\
\text { protection }\end{array}$} & \multicolumn{4}{|c|}{$\begin{array}{l}\text { 1. Has a healthcare provider informed you about } \\
\text { the usage of sunscreen, protection yourself from } \\
\text { the sun and wearing protective clothes? }\end{array}$} \\
\hline & \multirow{3}{*}{\multicolumn{2}{|c|}{ Yes }} & $\begin{array}{l}\text { The } \\
\text { dermatologist }\end{array}$ & $57(11.4)$ \\
\hline & & & $\begin{array}{l}\text { The family } \\
\text { physician }\end{array}$ & $15(3)$ \\
\hline & & & Others* & $8(1.6)$ \\
\hline & \multicolumn{3}{|l|}{ No } & $397(79.4)$ \\
\hline & \multicolumn{3}{|c|}{ Don't know/don't remember } & $23(4.6)$ \\
\hline
\end{tabular}

2. Has a heathcare provider informed you about the importance of the following changes of moles on your skin?

\begin{tabular}{|l|l|l|}
\hline \multirow{2}{*}{ Yes } & $\begin{array}{l}\text { The } \\
\text { dermatologist }\end{array}$ & $48(9.6)$ \\
\cline { 2 - 3 } & $\begin{array}{l}\text { The family } \\
\text { physician }\end{array}$ & $6(1.2)$ \\
\cline { 2 - 3 } & Others* & $6(1.2)$ \\
\hline No & $419(83.8)$ \\
\hline \multicolumn{2}{|l}{ Don't know/don't remember } & $21(4.2)$ \\
\hline
\end{tabular}

Counseling 3 . Has a heathcare provider informed you about on early detection of skin

cancer how to follow changes of moles on your skin?

Yes

\begin{tabular}{|l|l|}
\hline $\begin{array}{l}\text { The } \\
\text { Dermatologist }\end{array}$ & $42(8.4)$ \\
\hline $\begin{array}{l}\text { The Family } \\
\text { physician }\end{array}$ & $6(1.2)$ \\
\hline Others* & $6(1.2)$ \\
\hline & $417(83.4)$ \\
\hline
\end{tabular}

Don't know/don't remember $29(5.8)$

4. Has a heathcare provider told you that you should have a periodic check-up by a skin specialist?

\begin{tabular}{l|l}
\hline Yes & $66(13.2)$ \\
\hline No & $402(80.4)$ \\
\hline Don't know/don't remember & $32(6.4)$
\end{tabular}

5. How often do you use sunscreen or restricted your exposure to the sun?

Behavior

of sun protection

\begin{tabular}{|l|l|}
\hline Always & $10(2)$ \\
\hline Whenever I leave the house & $24(4.8)$ \\
\hline $\begin{array}{l}\text { Only when I am exposed for long } \\
\text { periods of time to the sun }\end{array}$ & $49(9.8)$ \\
\hline Sometimes & $70(14)$ \\
\hline Rarely & $40(8)$ \\
\hline Never & $307(61.6)$ \\
\hline
\end{tabular}

6. Do you closely observe moles on your skin for suspicious changes?

Behavior for the early detection of skin cancer

\begin{tabular}{l|l|}
\hline Yes & $120(24)$ \\
\hline Sometimes & $90(18)$ \\
\hline No & $290(58)$ \\
\hline $\begin{array}{l}\text { 7. Did you visit a skin specialist in order to have } \\
\text { your moles checked in the last year? }\end{array}$ \\
\hline Yes & $51(10.2)$ \\
\hline No & $439(87.8)$ \\
\hline Don't know/don't remember & $10(2)$ \\
\end{tabular}


Table 3. Evaluation of the relationship between the participants' counseling on early detection of skin cancer and behaviors

\begin{tabular}{|c|c|c|c|}
\hline \multirow{2}{*}{ Early detection counseling } & \multicolumn{3}{|l|}{ Early detection behavior } \\
\hline & Self-skin examination $\mathrm{n}(\%)$ & Annual check-up n (\%) & p \\
\hline \multicolumn{4}{|l|}{ Self-skin examination } \\
\hline Yes & $45(83.3)$ & $30(50)$ & $<0.001$ \\
\hline No & $150(36)$ & $20(4.8)$ & $<0.001$ \\
\hline \multicolumn{4}{|l|}{ How to monitor } \\
\hline Yes & $45(83.3)$ & $29(53.7)$ & $<0.001$ \\
\hline No & $150(36)$ & $18(4.3)$ & $<0.001$ \\
\hline \multicolumn{4}{|l|}{ Check-up } \\
\hline Yes & $38(57.6)$ & $33(50)$ & $<0.001$ \\
\hline No & 79 (19.7) & $14(3.5)$ & $<0.001$ \\
\hline
\end{tabular}

Table 4. Factors associated with sun protection counseling and behavior

\begin{tabular}{|c|c|c|c|c|c|c|}
\hline \multirow{2}{*}{ Variables } & \multicolumn{3}{|c|}{ M1. Sun protection counseling $(n=500)$} & \multicolumn{3}{|c|}{ M2. Sun protection behavior $(n=500)$} \\
\hline & OR & $95 \% \mathrm{Cl}$ & $\mathbf{p}$ & OR & $95 \% \mathrm{Cl}$ & $\mathbf{p}$ \\
\hline Age & 0.966 & $0.934-1.001$ & 0.047 & 0.963 & $0.938-0.988$ & 0.005 \\
\hline Education & - & - & 0.024 & - & - & $<0.001$ \\
\hline Primary & 1.559 & $0.523-4.643$ & 0.425 & 2.452 & $0.977-6.151$ & 0.056 \\
\hline Reporting having skin-cancer risk factors & 3.475 & $2.016-5.989$ & $<0.001$ & 1.010 & $0.665-1.533$ & 0.964 \\
\hline Sun protection counseling & - & - & - & 4.590 & $2.564-8.217$ & $<0.001$ \\
\hline \multicolumn{7}{|c|}{$\begin{array}{l}\text { Logistic regression models, odds ratio, } 95 \% \text { confidence interval and p-values. Reference categories: "woman" for gender, "illiterate" for educational background, "yes-groups" } \\
\text { for receiving sun protection counseling, and having risk factors of skin cancer, two different logistic regression models are used. M1, M2: In model 1, 2. 1., the sun protection } \\
\text { counseling variable was not taken as an independent variable } \\
\text { OR: Odds ratio, Cl: Confidence interval }\end{array}$} \\
\hline
\end{tabular}

\section{Table 5. Factors associated with the early detection behaviors}

\begin{tabular}{|c|c|c|c|c|c|c|}
\hline \multirow[t]{2}{*}{ Variables } & \multicolumn{3}{|c|}{$\begin{array}{l}\text { M1: Self monitoring of changes suspicious } \\
\text { of skin cancer (yes and sometimes) }(n=500)\end{array}$} & \multicolumn{3}{|c|}{$\begin{array}{l}\text { M2: Check-up by a physician for early detection of } \\
\text { skin cancer during the previous year }(n=500)\end{array}$} \\
\hline & OR & $95 \% \mathrm{Cl}$ & $\mathbf{p}$ & OR & $95 \% \mathrm{Cl}$ & $\mathbf{p}$ \\
\hline Gender & 1.101 & $0.695-1.742$ & 0.683 & 1.360 & $0.589-3.141$ & 0.471 \\
\hline Education & - & - & 0.030 & - & - & 0.404 \\
\hline University & 5.566 & $1.810-17.111$ & 0.003 & 0.910 & $0.181-4.560$ & 0.908 \\
\hline Sun protection behavior & 3.589 & $2.334-5.520$ & $<0.001$ & 0.607 & $0.255-1.443$ & 0.259 \\
\hline $\begin{array}{l}\text { Counseling on how to monitor } \\
\text { suspicious changes }\end{array}$ & 1.883 & $0.725-4.892$ & 0.194 & 5.914 & $2.180-16.043$ & $<0.001$ \\
\hline
\end{tabular}

than that of Baron-Epel and Azizi ${ }^{6}$. However, the rate of sun protection behaviors were higher. The regression analysis revealed that counseling is a factor that has an effect on behaviors. Therefore, we believe that increasing the effectiveness of primary prevention studies in the middle-aged and older groups can affect behaviors in a positive way in our population. In both studies, the rate of sun-protection behaviors 
was higher than that of counseling, this was considered that individuals have different sources of information on this subject. Supporting this data, the studies conducted by Robinson et al. ${ }^{10}$ and Haluza et al. ${ }^{11}$ reported that awareness related to sun protection increased through the media rather than healthcare professionals; however, the most effective results were obtained by means of information provided by the experts through the media. Therefore, we believe that the primary and secondary prevention studies by healthcare professionals through the media will increase the efficacy.

A study evaluating the effect of existing skin-cancer risk factors on counseling and behaviors found that those with risk factors had higher rates of having sun-protection counseling and behaving than those without any risk factor ${ }^{6}$. In our study, those with risk factors had significantly high rates of counseling, but the rate of sun protection behaviors were low. For this reason, we think that multi-dimensional studies are needed to increase the level of knowledge and awareness of sun protection for individuals with risk factors.

High level of education was thought to have a positive effect on sun protection behaviors, and it was considered that this might be related to the high level of the knowledge and awereness on necessity of sun protection $^{6}$. In our study, we observed that high level of education had positive effects on behaviors as in the literature ${ }^{6}$.

The study by Baron-Epel and Azizi ${ }^{6}$ determined that being older had positive effects on sun protection counseling. In our study, the presence of skin cancer risk factors and being a woman had a positive effect on sun protection counseling, unlike the negative effect of being older. Being older had also a negative impact on sun-protection behaviors. We observed that sun protection counseling and behaviors reduce as getting older. Therefore, we believe that new studies are necessary to improve primary prevention activities in middle-aged group, especially in elderly people who have increased risk of skin cancer.

In the survey study of Seité et al. ${ }^{12}$ with 9569 people from 23 countries, it was demonstrated that the primary and secondary prevention practices differed in countries; however, these were all insufficient. In the study of Geller et al. ${ }^{13}$ with 380 physicians from 50 different regions (approximately 40\% from high UV index regions), there was no difference between regions with high and low UV index in terms of sun protection counseling. Our study similarly revealed that the primary and secondary prevention activities were insufficient.

Eight-year health campaigns conducted for the early detection of melanoma in Italy led to a significant decrease in melanoma-related morbidity and mortality rates as well as the cost of treatment ${ }^{14}$. These results paved the way for professional studies to be carried out in Australia, Canada and many European countries aiming to improve primary and particularly secondary prevention activities in skin cancer ${ }^{15-19}$. The activities for early detection of skin cancer include studies that will increase the level of knowledge and awareness on the importance of following of skin lesions, following methods of moles and the necessity of an annual cheek-up. A study evaluating the effect of self-skin examination in the early detection of melanoma showed that it was an important factor decreasing the melanomarelated mortality rate by $63 \%{ }^{20}$. The evaluation by an expert beside self-skin examination helps the early detection of tumors, especially in terms of early minor changes that may be overlooked ${ }^{21}$. The reasons for overlooking changes in self-examination include visual impairment, many benign skin lesions complicating the detection of early malignant lesions, presence of other health problems with priority, lack of partner guiding the individual to the expert ${ }^{21}$. However there are contradictory results regarding the effectiveness of the counseling on the early detection of skin cancer $6,12,21$. In our study, the participants who received counseling on early detection of skin cancer were significantly more prone to early detection behaviors. In addition, counseling on the following method of moles and the necessity of annual expert controls had positive influence on attending to annual check-up. Therefore, we believe that counseling on early detection of skin cancer will be beneficial in its early detection.

\section{Study Limitation}

Our study has some limitations worth mentioning. Firstly, the data obtained from the survey questions, especially questions related to the existence of risk factors, were based on the statements of the participants. Besides, volunteers who agreed to participate in the survey consisted of individuals who applied to a tertiary hospital, so the results may not reflect the general population.

\section{Conclusion}

In the middle-aged and older groups, the rate of sun protection counseling and behaviors were insufficient. However, the sun protection counseling had a positive impact on behaviors. The rate of counseling for those who had skin cancer risk factors was higher than those who did not; however, sun protection behaviors were insufficient in this group as well. Being older had a negative influence on sun protection counseling and behaviors. Counseling on the early detection of skin cancer had a positive effect on early detection behaviors. Improvement of primary and secondary prevention activities in the middle-aged and older groups may contribute to the prevention and early detection of skin cancer

\section{Ethics}

Ethics Committee Approval: Before the study, ethical approval was received from the Tokat Gaziosmanpaşa University Faculty of Medicine Local Ethics Committee (approval number: 19-KAEK-016).

Informed Consent: Informed consent was obtained.

Peer-review: Externally and internally peer-reviewed.

\section{Authorship Contributions}

Concept: A.O., Design: A.O., Data Collection or Processing: A.O., Analysis or Interpretation: A.O., O.D., Literature Search: A.O., Writing: A.O.

Conflict of Interest: No conflict of interest was declared by the authors.

Financial Disclosure: The authors declared that this study received no financial support.

\section{References}

1. Sümen A, Öncel S: Türkiye'de cilt kanseri ve güneşten korunmaya yönelik yapılan araştırmaların incelenmesi. Turkiye Klinikleri J Nurs Sci 2018;10:5969.

2. Ceylan C, Öztürk G, Alper S: Non-melanoma skin cancers between the years of 1990 and 1999 in Izmir, Turkey: Demographic and clinicopathological characteristics. J Dermatol 2003;30:123-31.

3. Balcı E, Durmuş $H$, Ergün Arslantaş $E$, Gün I: Birinci basamak sağlık kuruluşlarına başvuran yetişkinlerin güneşin zararlı etkileri ve korunma 
yolları konusunda bilgi, tutum ve davranışları. Turk J Dermatol 2018;12:96-9.

4. Whiteman DC, Whiteman CA, Green AC: Childhood sun exposure as a risk factor for melanoma: A systematic review of epidemiologic studies. Cancer Causes Control 2001;12:69-82.

5. Henrikson NB, Morrison CC, Blasi PR, Nquyen M, Shibuya KC, Patnode CD: Behavioral counseling for skin cancer prevention: Evidence report and systematic review for the US Preventive Services Task Force. JAMA 2018;319:1143-57.

6. Baron-Epel O, Azizi E: The association between counseling, sun protection, and early detection of skin cancer in middle-aged Israelis. Cancer Detect Prev 2003;27:338-44.

7. D'Orazio J, Jarrett S, Amaro-Ortiz A, Scott T: UV radiation and the skin. Int J Mol Sci 2013;14:12222-48.

8. Alataş ET, Kara Polat A, Doğan G, Pıçakçıefe M: Akademik personelin güneşten korunma ve güneş koruyucu kullanımıyla ilgili bilgi, tutum ve alıskanlıklarının değerlendirilmesi. Turk J Dermatol 2018;12:9-17.

9. Feldman SR, Fleischer $A B$ Jr: Skin examinations and skin cancer prevention counseling by US physicians: A long way to go. J Am Acad Dermatol 2000;43:234-7.

10. Robinson JK, Rigel DS, Amonette RA: What promotes skin self-examination? J Am Acad Dermatol 1998;38:752-7.

11. Haluza D, Schwab M, Simic S, Cervinka R, Moshammer H: Perceived relevance of educative information on public (skin) health: Results of a representative, population-based telephone survey. Int I Environ Res Public Health 2015;12:14260-74.

12. Seité $S$, Del Marmol V, Moyal D, Friedman AJ: Public primary and secondary skin cancer prevention, perceptions and knowledge: an international crosssectional survey. J Eur Acad Dermatol Venereol 2017;31:815-20.
13. Geller AC, O'Riordan DL, Oliveria SA, Valvo S, Teich M, Halpern AC: Overcoming obstacles to skin cancer examinations and prevention counseling for high-risk patients: Results of a national survey of primary care physicians. J Am Board Fam Pract 2004;17:416-23.

14. Cristofolini M, Bianchi R, Boi S, et al: Analysis of the cost-effectiveness ratio of the health campaign for the early diagnosis of cutaneous melanoma in Trentino, Italy. Cancer 1993;71:370-4.

15. Hill D, Marks R, Boulter J: Public health approaches to skin cancer control. Australas J Dermatol 1997;38(Suppl 1):73-8.

16. Marks R: Two decades of the public health approach to skin cancer control in Australia: Why, how and where are we now? Australas J Dermatol 1999;40:1-5

17. Koh HK, Geller AC: Public health interventions for melanoma. Prevention, early detection, and education. Hematol Oncol Clin North Am 1998;12:90328.

18. Rivers JK, Gallagher RP: Public education projects in skin cancer. Experience of the Canadian Dermatology Association. Cancer 1995;75(2 Suppl):661-6.

19. Azizi $E$, Flint $P$, Sadetzki $S$, et al: A graded work site intervention program to improve sun protection and skin cancer awareness in outdoor workers in Israel. Cancer Causes Control 2000;11:513-21.

20. Berwick M, Begg CB, Fine JA, Roush GC, Barnhill RL: Screening for cutaneous melanoma by skin self-examination. J Natl Cancer Inst 1996;88:17-23.

21. Marks R: Prevention and control of melanoma: the public health approach. CA Cancer J Clin 1996:46:199-216. 